\title{
Early Medieval Central Asian Population Estimates
}

\author{
Étienne de la Vaissière \\ EHESS, PSL, Paris \\ edlv@ehess.fr
}

\begin{abstract}
Census data from 8th-century Eastern Central Asian oases, combined with the measurements of the oases and data from archives discovered there, allow us to calculate estimates both of the individual oases' populations and of their respective feeding capacities, which is to say the number of people who could be fed from the output of one hectare of agricultural land. These numbers in turn have parallels in Western Central Asia, where oasis sizes can also be calculated by examination of preserved archaeological landscapes and oasis walls. It is therefore possible to reach a rough idea of the populations dwelling in the main oases and valleys of sedentary Central Asia. As regards nomadic regions, the data are far more hypothetical, but references in certain sources to the sizes of nomad armies and rates of nomadic military levying can allow us to calculate at least the possible scales of magnitude for populations living to the north of the Tianshan.
\end{abstract}

\section{Keywords}

Paleodemography - Central Asia - Middle Ages - Irrigation - Nomads - Census

\section{Introduction}

This article is an attempt to provide very rough estimates of Central Asian populations in the 8th century, with three different methodologies on three different regions, and with results in a decreasing order of reliability. What will be sought here are orders of magnitude, as well as a global understanding of the demographic balance between the oases of Eastern Central Asia (including the Tarim and Turfan Basins, Hami, Qarashahr and Dunhuang); Western 
Central Asia (here understood as Bactria and Sogdia); ${ }^{1}$ and the nomad-dominated region between the Tianshan and the Syr Daria in the south, up to northern Kazakhstan and the Altay in the north.

As we shall see, these three regions differ in terms of the range, specificity and reliability of the sources pertaining to each of them. The results of the Tang period Chinese census for the oasis settlements of Eastern Turkestan are quite reliable: the population was totally dependent on a single irrigation network, and thus easily controllable and countable. Arabic-language texts describing to Western Central Asia, although more qualitative than quantitative, are generally from eyewitnesses. For some oases the dimensions of extant oasis walls allow us to calculate the area of enclosed agricultural land, while the distribution of archaeological sites provides a repartition pattern. Taken together, these data actually combine quite well, once it has been taken into account that they provide very rough estimates, and usually, for methodological reasons, minima. The problem is rather on the blank spots of the map, the regions for which we have nothing: our Sudoku has too many white squares. But still, this gathering of as much data as possible has the added benefit of some interesting historical results.

\section{Eastern Central Asia}

For the region of Eastern Central Asia, what little precise demographic information we have to hand comes from the Chinese census of the 730 and $740{ }^{2}{ }^{2}$ The census results are preserved in the Tongdian, an encyclopaedia of the administration making use of actual records, written before $801,{ }^{3}$ and the Yuanhe junxian tuzhi, a geographical treatise written before $814{ }^{4}$

The census was applied to these oases because they were regarded as regular Chinese prefectures, while the oases further to the west, Qarashahr, Aqsu,

1 We have no data at all on Khorezm and I will deal in a separate article with the region of Margiana.

2 There were several censuses in the first half of the 8th c. On the Chinese census see H. Bielenstein, "The Census of China during the Period 2-742 AD." Bulletin of the Museum of Far Eastern Antiquities 19 (1947): 125-163. See also J.K. Skaff. Straddling Steppe and Sown: Tang China's Relations with the Nomads of Inner Asia (640-756). (Unpublished Ph.D. Dissertation, University of Michigan. 1998): 365-379 on the 8th c. data, especially on Xizhou.

3 Du You 杜佑, Tongdian 通典 (Beijing: Zhonghua shuju., 1988): 174 : 4554-4559.

4 Li Jifu李吉甫, Yuanhe junxian tuzhi 元和郡縣圖志. (Beijing: Zhonghua Shuju, 1983): 40: 1025-1031. 


\begin{tabular}{lrrr}
\hline & $\begin{array}{l}\text { Tongdian } \\
\text { (inhabitants) }\end{array}$ & $\begin{array}{l}\text { Tongdian } \\
\text { (households) }\end{array}$ & $\begin{array}{l}\text { Yuanhe junxian tuzhi } \\
\text { (households) }\end{array}$ \\
\hline Hami & 8,756 & 2237 & 1729 \\
Xizhou & 50,340 & 11193 & 11647 \\
Beiting & 9,715 & 2398 & 2676 \\
Dunhuang & 32,234 & 6395 & 6466 \\
\hline
\end{tabular}

Kashgar, Yarkent, Tashkurgan, Khotan, were still nominally independent kingdoms and, as such, excluded from the census; Kucha, by contrast, was included in the survey.

The results for Dunhuang and Xizhou (the Turfan Basin) are especially interesting as the variations between the two sources are negligible.

\subsection{Dunhuang}

At Dunhuang, the numerous documents discovered in the grotto of Dunhuang make it possible to calculate the irrigated surface of the oasis, $146 \mathrm{~km}^{2}$, or 270,000 Chinese $m u .{ }^{5}$ The population being c. 32,000 inhabitants, this means that Dunhuang could sustain approximately 2 people per hectare.

However this result is not of immediate use for Central Asia as a whole. First of all, the crops under cultivation in Dunhuang - millet, hemp, soybean, rice, but little wheat and almost no grapes 6 - were quite different from the standard Central Asian agriculture prevalent in the other oases, reflecting Dunhuang's long Chinese history. Furthermore, since Dunhuang was for centuries the last military outpost of Gansu and could be easily provided with grain from the oases of northern Gansu (Zhangye, etc.), we cannot be sure that the inhabitants of the oasis were fed only with the products of their own agriculture.

\section{$1.2 \quad X i z h o u$}

In view of the two problems outlined immediately above, Xizhou-i.e. the Turfan region-, offers a more promising model than Dunhuang for evaluating the feeding power of Central Asian agriculture: the agriculture is of Central

5 Su, Jinhua 苏金花, “Monographic Study on Agriculture of Dunhuang during the Tang and Five Dynasties 唐五代敦煌农业专题研究, 中国社会科学院研究生院 2002: 10.

6 É. Trombert, Le crédit à Dunhuang (Paris: Collège de France, 1995): 38 sq. 
Asian type, based on wheat, grapes, and fruits. ${ }^{7}$ Xizhou is separated from Gansu by the Gobi and could not be fed from the south: a horse cart with half a ton of grain sent from Zhangye would be $2 / 3$ empty when it arrived at Xizhou (and $40 \%$ empty if sent from Dunhuang). There were however some military farms north of the Bogdashan, but these were not very productive lands and fed only or mainly the local garrisons. The Xin Tangshu gives 49,476 inhabitants, ${ }^{8}$ the Tongdian 50,340. Dividing the number of inhabitants by the number of households (c. 11,500) gives the average size of the household, 4.5 to $5 .{ }^{9}$

\subsection{Kucha, Hami, Beiting, Qarashahr}

We have fewer data regarding the other oases of the region. Judging from the figures above, Hami probably had c. 10,000 inhabitants, and Beiting 12,000. The Tongdian gives slightly lower figures, ascribing 8,756 inhabitants to Hami, and 9,715 to Beiting. It also ascribes to Kucha 11,106 households, ${ }^{10}$ and 63,168 inhabitants. It seems that Kucha was included in the census survey because it served as the headquarters of the Chinese army, although still an independent kingdom not officially subject to the Chinese census. When Qarashahr was conquered by the Chinese in 640 , it had approximately half the number of households as Xizhou — some 4000—," ${ }^{11}$ which might suggest a total population of 18-20,000 inhabitants around that time, though we have little demographic data for the decades thereafter.

\section{$1.4 \quad$ Missing Data: Khotan, Yarkent, Kashgar and the Small Oases}

The absence of demographic data is particularly problematic in the case of Khotan, which was certainly a very big oasis: politically it seems to have been at least on par with Kucha. The map drawn by A. Stein at the beginning of the 2oth century still shows an irrigated area of c. 1,400 km², 10 times the irrigated area of medieval Dunhuang, and twice as big as the oasis of Kucha on the same maps. ${ }^{12}$ Actually, as seen from the location of several Buddhist monasteries now engulfed by the sands, the area of the medieval oasis of Khotan and its dependencies on lateral streams was probably even larger than this. The only textual information we have-a reference in the Tongdian to

7 É. Trombert, "La vigne et le vin en Chine: Misères et succès d'une tradition allogène." Journal asiatique 290/2 (2002): 487-490.

8 Ouyang Xiu 歐陽修, Xin Tangshu 新唐書 (Beijing: Zhonghua shuju, 1975): 40: 1046.

9 J.K. Skaff, Straddling Steppe and Sown: 370.

10 Du You 杜佑, Tongdian 通典: 174: 4559 .

11 Ouyang Xiu 歐陽修, Xin Tangshu 新唐書: 221a: 6228.

12 A. Stein, Serindia (Oxford: Clarendon Press. 1921): vol. 5, sheets 20, 34. 
32,00o households-, is copied from a Later Han period source. ${ }^{13}$ A Tibetan source of the 8th century gives the number of monks and nuns in the oasis, 11,400, ${ }^{14}$ which should be compared with Kucha's 11,106 households: there were more monks and nuns in Khotan than households in Kucha. But many of these monks were in fact peasants, coming to the monastery only at major festivals, so that they should be an important part of the Buddhist population of the oasis. The same source lists more than 5,00o shrines, most of them private. Conversely, when conquered by the Chinese, Khotan could muster only 4,000 soldiers, the same number as Kucha. An educated guess might be that Khotan was more than two or three times more populous than Kucha, and it might also be possible that the Han data of 32 ,ooo households was repeated also because it was still roughly correct. ${ }^{15}$

We have no data at all on the population of Kashgar, Yarkent, Aqsu and the very small oases all around the Taklamakan desert.

\subsection{Chinese Population in the Oases}

A document of the 740 s from Dunhuang, a geographical list of tribute from Chinese prefectures, provides us with the household figures in the Four Garrisons of the Chinese army in the Tarim, i.e. in Kucha, Khotan, Kashgar and Qarashahr. ${ }^{16}$ The document reads as follows:

龜茲都督府戶四千九百七十四在安西城內無本

烏耆府戶一千一百六十七去安 $[\cdots]$ 無本

于闐毗沙府戶四千四百八十七安西南二千里無本

踈勒府戶一千八百六十安西 $[\cdots]$ 二月敕新置無本

The governor's office in Kucha(Qiuci):4974 households. Located inside the town of Anxi. Without origin.

The office of Qarashahr (Wuqi): 1167 households, to An[xi] [...] Without origin.

13 Du You 杜佑, Tongdian 通典: 192: 5224.

14 R.E. Emmerick, Tibetan Texts Concerning Khotan (Oxford University Press. 1967): 73-75.

15 A late 1oth-century Muslim source gave 70,000 soldiers to the kingdom, but also 20,000 to Qarashahr, a fact that might be interpreted as demonstrating a gross exaggeration in both numbers: Hudūd al-'Alam: "The Regions of the World". A Persian Geography, 372 A.H.-982 A.D., translated and explained by Vladimir Minorky (London: Luzac 1970): 86, 94.

16 Wu Zhen 吴震, "Edition and Commentary of the Junxian Gongxie Benqian Bu 敦煌石室 写本唐天宝初年<郡县公廨本钱簿〉校注并跋." Wenshi 文史 93 (1982): 97-98. 
The office of Pisha, Khotan (Hetian): 4487 households, at 2,00o li to the south from Anxi. Without origin.

The office of Kashgar (Shule): 186o households, to Anxi [...] Newly established the second month by Imperial order. Without origin.

These figures have been regarded by some scholars as the actual populations of these oases: the fact that they are very low was supposed to reflect the decline of these populations in the Tarim Basin since the Han period. ${ }^{17}$ But it is much more likely that they count only the Chinese civil population of the oases, with no recorded origin, and not the whole population: Qarashahr would have lost $3 / 4$ of its population in one century while the 4,974 figure for Kucha cannot be compared to the 11,106 households of the Tongdian. The Four Garrisons were major military control points, with c. 24,000 soldiers established there. ${ }^{18}$ The c. 12,500 families mentioned in the Dunhuang document might be linked with the transition from a conscription-based rotating army to a permanent army, settled with the families on the frontiers, that China was experiencing during this very period. ${ }^{19}$ These numbers might reflect non-taxable families of the soldiers, if half of them were married. In that case we should add to the 24,000 soldiers approximately 44,000-50,000 civilians (i.e., counting a standard average family of 4.5-5 minus the soldier himself, i.e. 3.5-4 nonsoldiers/household), which would yield a total of c. 68,000-74,000 Chinese in these oases in 742. If these families were not those of the soldiers, a much less likely hypothesis, then the total would reach 80,000-86,00o Chinese in these four oases $(12,500 \times(4.5$ or 5$)+24,000)$, to which should be added the families of the soldiers. Furthermore, if the number of Chinese households in the document is more or less proportionate to the number of soldiers, a quite likely hypothesis, then there should have been, out of 24,000 soldiers, c. 9-10,000 in Kucha, the headquarters, c. 8-9,000 in Khotan, c. 3,500 in Kashgar and c. 2,500 in Qarashahr.

\subsection{Demography and Acculturation}

These numbers are extremely important for the understanding of what was going on culturally in the 8th-century Tarim basin. If we accept as it stands the figure of 11,106 native households in the Kucha oasis, then this means that Chinese control added to them 4,974 Chinese households, and c. 9-10,000

\footnotetext{
17 Yin Qing 殷晴, The Silk Road and the Economy of the Western Regions (丝绸之路与西域 经济) (Beijing: Zhonghua Shuju. 2007): 375.

18 Du You 杜佑, Tongdian 通典: 172: 4479.

19 D. Graff, Medieval Chinese Warfare 300-900 (Abington: Routledge, 2003): 209.
} 
soldiers on top of these households, or among them. The burden on the Kucha kingdom would have been enormous, particularly given that the same text states that the Chinese headquarters of the whole Four Garrisons system were installed within the capital itself. In the other oases the Chinese garrison was usually outside of the main town, whether in a newly-established settlement nearby, as in Kashgar, ${ }^{20}$ or in the lateral alluvial fan of Pisha in Khotan. The sharp decline of Kuchean culture in the 7 th-8th centuries, as well as the control of the kingdom that local Chinese generals managed to keep after breaking ties with Central China in the middle of the 8th century, might both be explained in this regard: there should have been c. 30,00o Chinese there, compared to c. 63,00o Kucheans. The situation was similar in Xizhou in the 5th century, when the local culture was overwhelmed by an influx of Chinese refugees from Gansu and eventually disappeared. One would expect Chinese demographic pressure to have been less in Khotan, where some 25,000 to 30,000 Chinese may have settled in the oases of the kingdom, encountering a local population of most probably over 150,000 . Such a military presence allowed the Chinese garrison to keep a tight control on the Khotan oasis well beyond the breaking of ties with China, but did not overwhelm the local culture: indeed, Khotan flourished up until the Muslim conquest at the beginning of the 11th century.

\subsection{Feeding Xizhou: Productivity of the Central Asian Agricultural Mix}

The figure of c. 50,00o inhabitants in Xizhou is a number for the whole prefecture, a desert basin in which the population was settled in the 5 small peripheral oases of Gaochang, Jiaohe, Liuzhong, Tianshan, and Puchang. We do not have the number of inhabitants for each oasis, but each of them was at least described in standardized categories of settlements: large (more than 5,000 households), middle (from 2,00o to 5,00o households), middle-small (1,00o to 2,000 households), or small (less than 1,00o households). ${ }^{21}$ The main town was Gaochang, a large settlement according to the Xin Tangshu, while Jiaohe was within the 1,000 to 2,000 households range, Liuzhong and Tianshan both in the less than 1,000 range, and Puchang in the 2000 to 5,000 range, but certainly close to 2,000 as in an earlier census it was regarded as a middle-small settlement. J. Skaff, in his detailed analysis of these numbers, has made clear that Gaochang should be in the 5,800 to 7,500 households range, that is 26,100 to 37,500 inhabitants. ${ }^{22}$

\footnotetext{
20 Ouyang Xiu 歐陽修, Xin Tangshu 新唐書: 43b: 1150.

21 Skaff, Straddling Steppe and Sown: 371.

22 Ibid.: $375^{-6}$.
} 
But the interesting point has been misunderstood up to now. In the following passage, the Tongdian specifies the irrigated area of the Gaochang oasis. ${ }^{23}$

The territory [of the Gaochang county] was transformed into the Prefecture of the West (originally the dimensions of the kingdom of Gaochang were an east-west length of $800 \mathrm{li}$ and a north-south width of 500 li). Its cultivated area is 900 qing.

以其地為西州, 本高昌國界, 東西八百里, 南北五百里, 墾田九百 頃。

V. Xiong, in a detailed study of the productivity of agriculture in the Xizhou region, took the above passage to indicate that the specified area of goo qing. [= 4,800 hectares] was the total irrigated land for the whole prefecture. Dividing the given figure of 4,80o hectares by the total c. 50,000-strong population of the prefecture, he came to the remarkable conclusion that an average hectare of irrigated land could support as many as 10 inhabitants. ${ }^{24}$

However it is enough to have a look at the map or a satellite image to realize that the specified 4,80o-ha. area is the size of only the central part of the Gaochang alluvial fan on the foothills of the Flame mountains (Map 1). A century ago, as we see from Aurel Stein's maps, an area here of some 11,000 ha., i.e. $110 \mathrm{~km}^{2}$, was watered by a qarez irrigation system..$^{25}$ Today an area of c. 20,000 ha. $\left(200 \mathrm{~km}^{2}\right)$ is irrigated with motor pumps. But 4,80o hectares is a minimum, fitting perfectly well between the various cemeteries of the oasis, which were situated at the outer limits of the cultivated lands (the proposed drawing of the irrigation network, surrounding Gaochang, is based on texts but approximate). ${ }^{26}$

It is plainly impossible that the figure of 4,800 hectares could pertain to the total irrigated area of all 5 oases of the Turfan Basin. Evidently, then, a confusion has crept into the text conflating Gaochang qua oasis with Gaochang qua kingdom: actually the whole paragraph deals with Gaochang as an oasis (a Chinese county), and as the center of the various Chinese administrations in the region. It is the preceding paragraph that deals with the whole kingdom

\footnotetext{
23 Du You 杜佑, Tongdian 通典: 174: 4558.

24 V.C. Xiong, "The Land-Tenure System of Tang China-A Study of the Equal-Field System and the Turfan Documents." T'oung Pao 85 (1999): 382.

25 Stein, Serindia: vol. 5 , sheet no. 59.

26 Yin Qing 殷晴, The Silk Road and the Economy of the Western Regions: 205 gives the general pattern of the network as reconstituted from the texts, adapted here.
} 


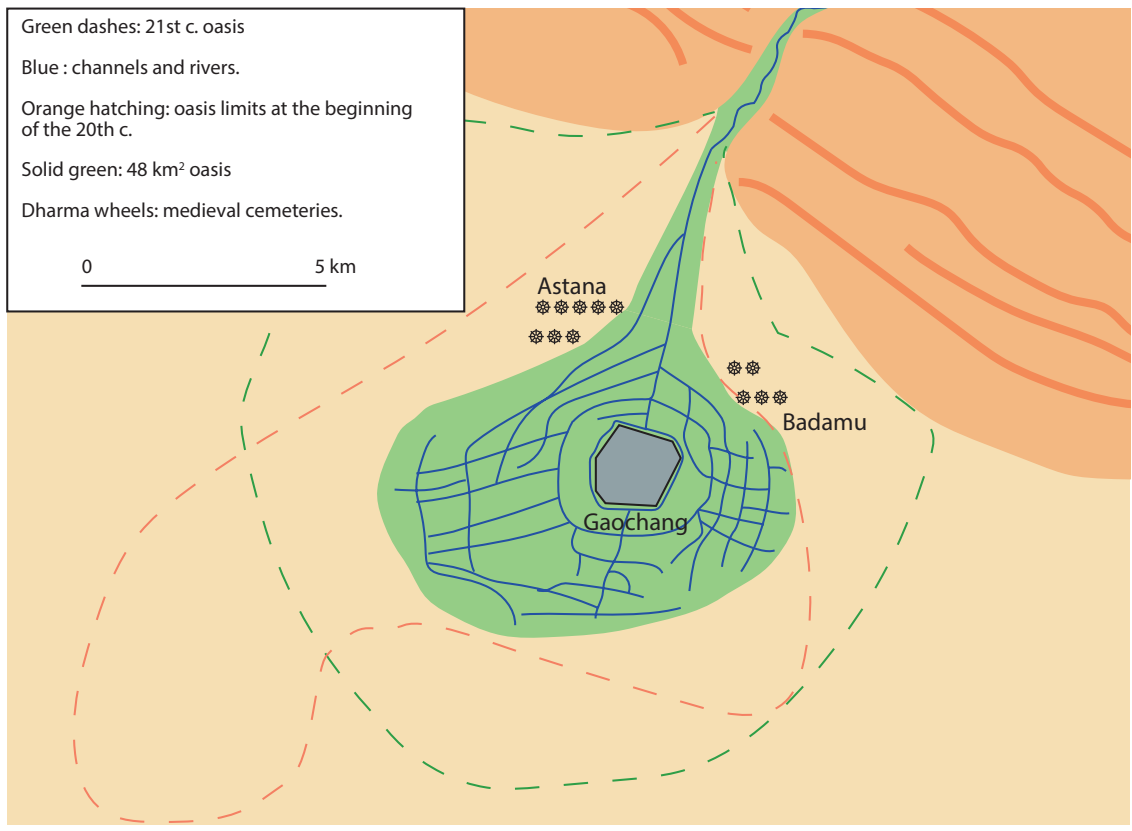

MAP $1 \quad$ The Gaochang oasis.

(the Chinese prefecture), and gives its number of households and inhabitants. If the irrigated area was that of the whole prefecture, it should have been in this preceding paragraph. ${ }^{27}$

27 The paragraph on Gaochang begins with "Now Xizhou is administrated from the Gaochang county," goes on in describing the administrative history of the Gaochang oasis (and this oasis only, as the Western part of the Turfan basin was under local kings from the Han to the $\mathrm{Qu}$ ), explains that its land became the Western prefecture when it was conquered by the Tang and then that 本高昌國界, 東西八百里, 南北五百里. The fact that Du You added "kingdom" (國) after Gaochang when describing its size while elsewhere he is dealing with the county (縣) proves that it is only as a parenthetical element. Then, we have the interesting part: 墾田九百頃 and after that, the text goes on explaining how Gaochang - the oasis—became the headquarters of the military commanderies/protectorates dealing with the West and Northwest. Does the phrase about the irrigated land belong to the preceding part, on the kingdom, or to the general topic of the paragraph, the county? The later editors of the Tongdian decided for the former, adding a comma before and a full stop after these five characters, but we are now in a position, knowing the map and the fact that the whole paragraph deals with the county, to see that it was a mistake. 
The Gaochang oasis of 4,800 ha., then, was feeding c. 30,000 inhabitants. However, there is a second difficulty. It is well known that, unlike anywhere else in Xinjiang, the climate of Xizhou allowed a double harvest on part of the irrigated land; it is to these two harvests that the terms Butian and Changtian refer in our documents. ${ }^{28}$ The portion of the lands yielding double harvests has been estimated at one third of the whole area, so to allow comparison with oases without the double harvest we should add the productive capacity of another 1,60o hectares to the 4,80o-ha. area of Gaochang, giving an equivalent of a productive capacity of 6,400 hectares. This productive capacity fed 30,000 inhabitants. It would mean in a Central Asian context without the double harvest c. 4.5 inhabitants for one hectare.

However this figure has been calculated from transmitted official sources. We are fortunate enough to be able to check it with numerous 8th-century documents dealing with agriculture at Xizhou.

Land of not very high fertility in the oasis was able to feed 2.1 people per hectare: this is clear from a document describing a plot of army land, i.e. a marginal one, able to provide $8.25 \mathrm{dou}$ of $\mathrm{mi}$ for each $\mathrm{mu}$, that is 933 liters of millet per hectare, this being equivalent by the standard ratio to 1.2 liters of millet per person per day, or 438 liters per person per year. ${ }^{29}$ Usually, the harvest on more fertile lands generated at least twice this amount of grain, as estimated from the amount of the rent, and the land able to feed 4.2 people per hectare. The best lands in Gaochang were producing 3,6oo liters or more of wheat on one hectare, and were able to feed more than 7 people per hectare. ${ }^{30}$

With these precise data, from daily documents dealing with actual agricultural fields in Gaochang, we can see that the estimate of c. 4.5 per hectare is certainly within the believable range, halfway between the productivity of the worst and best lands of the oasis. If some of the grain from Beiting was sent south to feed part of the population in Gaochang in addition to the army, it could have been only a small part of it and we might settle on a minimal approximate value of $4 \mathrm{p}$./ha, meaning that 4 people per hectare might be fed by the Central Asian agricultural mix, with its irrigated agriculture, orchards, vineyards, and livestock.

\footnotetext{
28 Xiong, "The Land-Tenure System of Tang China"; É. Trombert, "Les cycles de culture et l'organisation des terroirs à Tourfan aux VI ${ }^{\mathrm{e}}$-VIII ${ }^{\mathrm{e}}$ siècles." Bulletin de l'Ecole française d'Extrême-Orient 89 (2002): 203-235.

29 Skaff, Straddling Steppe and Sown: 245; Xiong, "The Land-Tenure System of Tang China.": 380-1.

$30 \quad$ Ibid.: 257 .
} 
This value can be compared to the figure of 2 people per hectare supported by the Chinese agricultural system in Dunhuang: the Central Asian agricultural mix, with its diversified intakes, could feed at least twice as many people as in Dunhuang, and 3.5 as many as the average inland Chinese agriculture: this is a lot, a fact reflected in the astonishment of Chinese depictions of Gaochang agriculture, but only half of the 1:7 rate between inland China and Xizhou calculated by V. Xiong. ${ }^{31}$

\subsection{Conclusion: A Population Estimate for the Oases of 8th-Century Eastern Central Asia}

The afore-mentioned absence of demographic information pertaining to Khotan and other non-documented oases significantly complicates any attempt to provide robust estimates for the total population of Eastern Central Asia. With due caution, however, we may nevertheless proceed. Except for the case of Khotan itself, it is unlikely that any of the non-documented oases should have had a population above the range of 10 to 20,000 inhabitants, given the fact that they seem to have been politically negligible in comparison with the likes of Kucha (c. 60,00o inhabitants) or Qarashahr (c. 20,000). If, then, we count 20,00o for Tashkurgan, Yarkent, Kashgar, Aksu, Uch-Turfan, adding 100,000 inhabitants - most certainly an over-estimation - and again 20,000 inhabitants in total for the very small oases and isolated villages, then we would arrive at a total for the settled population of Eastern Central Asia, from Hami and Dunhuang to Kashgar and Tashkurgan of c. 450,000 inhabitants plus or minus 150,000 , mainly due to Khotan, which is to say between minimum and maximum possible outliers of 300,000 and 600,000 . This result is admittedly highly imprecise, with the high end of the estimate range fully twice the low end. But it gives an order of magnitude for comparison with the other parts of Central Asia. The Hanshu, in its detailed account of the situation in the 1st century ВС, ascribed to Eastern Central Asia a population of some 250,000 inhabitants: ${ }^{32}$ assuming limited growth, we may hope to have erred on the right side of the historical truth.

\footnotetext{
31 Xiong, "The Land-Tenure System of Tang China": 380.

32 E. Trombert, "Notes pour une évaluation nouvelle de la colonisation des contrées d'Occident au temps des Han." Journal Asiatique 299/1 (2011): 67-123 who demonstrates that there was no causal relationship between the population growth in Eastern Turkestan and the Han colonisation, pace E. Zürcher, "Han Buddhism and the Western Region." In Thought and Law in Qin and Han China. Studies dedicated to Anthony Hulsewé on the occasion of his eightieth birthday ed. W. L. Idema and E. Zürcher (Leiden: Brill, 1990): 158-182.
} 
The situation west of the Pamirs is entirely different. No medieval census ever counted the inhabitants, or at least none was preserved. ${ }^{33}$ The only numerical data are to be found in historical narratives. We can isolate several subregions corresponding to the main oases and valleys, for instance the Bactra, Bukhara and Marw oases, the middle Zarafshan valley or the delta of the Amu Darya. These were basically autonomous as regards food, separated from other regions as they were - and as they remain today—by extensive tracks of deserts; trade in bulk goods such as grain is attested in Central Asia during this period only for armies on the move or within oases or valleys. The only way grain could be sent at an acceptable cost was on rivers downstream. Reconstructing the demography of Western Central Asia is complicated by the fact that the oasis geography of its constituent sub-regions was significantly altered by Soviet engineering projects. Individual oases have more water than they ever previously received; one thinks of the oasis of Marw, for instance, which presently receives much of its water from the Amu Darya through the $1,400 \mathrm{~km}$-long Qaraqum canal. The inner organization of these oases has been deeply modified, as too has the agricultural mix.

The methodological difficulties thus facing us are perhaps mitigated, however, by two facts:

1. The main oases of Western Central Asia, except for Khorezm, share a very interesting feature for our purpose: oasis walls and well-preserved archaeological landscapes, due to the incastellamento, the building of castles which took place all over these oases from the 4 th century onward. This allows us to calculate the approximate extent of early-medieval irrigated lands in Western Central Asia with greater ease than is the case with Eastern Central Asia; unlike with Eastern Central Asia, our greater problem is with estimating population densities.

2. Afghan oases, especially those in the north such as Balkh and Khulm/ Tashkurgan, were not subjected to the sorts of large-scale hydrographic modifications like those undertaken in the former Soviet Union. Up to the 1970s, they were scarcely impacted by modern techniques to the point of radically modifying their water distribution system and patterns, except for very limited attempts. After that, the Afghan war froze everything.

33 W. al-Qāḍī, "Population Census and Land Surveys under the Umayyads (41-132/661-750)." Der Islam 83 (2008): 341-416. 
One single oasis combines these two favorable features, the oasis of Balkh. The data we might gather from it will be useful for the other oases.

\subsection{Bactra}

The irrigation techniques in the Balkh oasis remained largely unchanged from Middle Ages right down until the 1970s. While some major irrigation improvements took place in other parts of Afghanistan -in the Helmand basin for instance-, very little work was done to improve the agriculture of Balkh before the beginning of the war in Afghanistan, and none during the war.

To ascertain the population of the Balkh region, we need, as before, to consider both the area of the region in question and its population density. One helpful clue for determining the area is a surviving 3 rd-century oasis wall, which served to delimit the useful agricultural area during the period of Late Antiquity; ${ }^{34}$ a further set of clues can be found in a remarkably well-preserved archaeological landscape - the oasis is literally dotted with fortresses, castles or stupas (Map 2). The situation could not be more different from the equally vast Khotan oasis for which we have no wall nor remains inside the oasis.

A very basic and large-scale geo- and hydrographical history of the oasis is possible for Balkh and its river, the Balkhab, if we consider the region both trans-regionally and diachronically. The fine-grained characteristics are beyond reach, but some broader outlines are reasonably clear. For instance the Nahr-e Shahi region was newly irrigated in the 2oth century and indeed is devoid of ancient monuments: it should be excluded.

An interdisciplinary team, combining archaeological, geomorphological and hydrological analysis, has studied this history. ${ }^{35}$ Their study established a complex four-stage process of evolution for the Holocene alluvial fan of the Balkhab, with first a Bronze-Age stage, an Achaemenid stage, a KushanoSasanian stage and then a final stage extending from sometime after the Islamic conquest to the present day. This means that we have to take into account one single major evolution in the history of oasis over the period from the 8th century to the present, namely that from the Kushano-Sasanian stage to the Islamic one. This evolution saw a major shift in the course of the river, which moved from a south-north-easterly direction to a western one, that is, to

34 É. de La Vaissière, Ph. Marquis, J. Bendezu-Sarmiento, "A Kushan Military Camp?" In Sources on the History of the Kushans, ed. H. Falk (Bremen: Hempen Verlag, 2015): 241-254.

35 E. Fouache, R. Besenval, C. Cosandey, C. Coussot, M. Ghilardi, S. Huot, M. Lamothe, "Palaeochannels of the Balkh River (Northern Afghanistan) and Human Occupation since the Bronze Age Period." Journal of Archaeological Science 39 (2012): 3415-3427. 


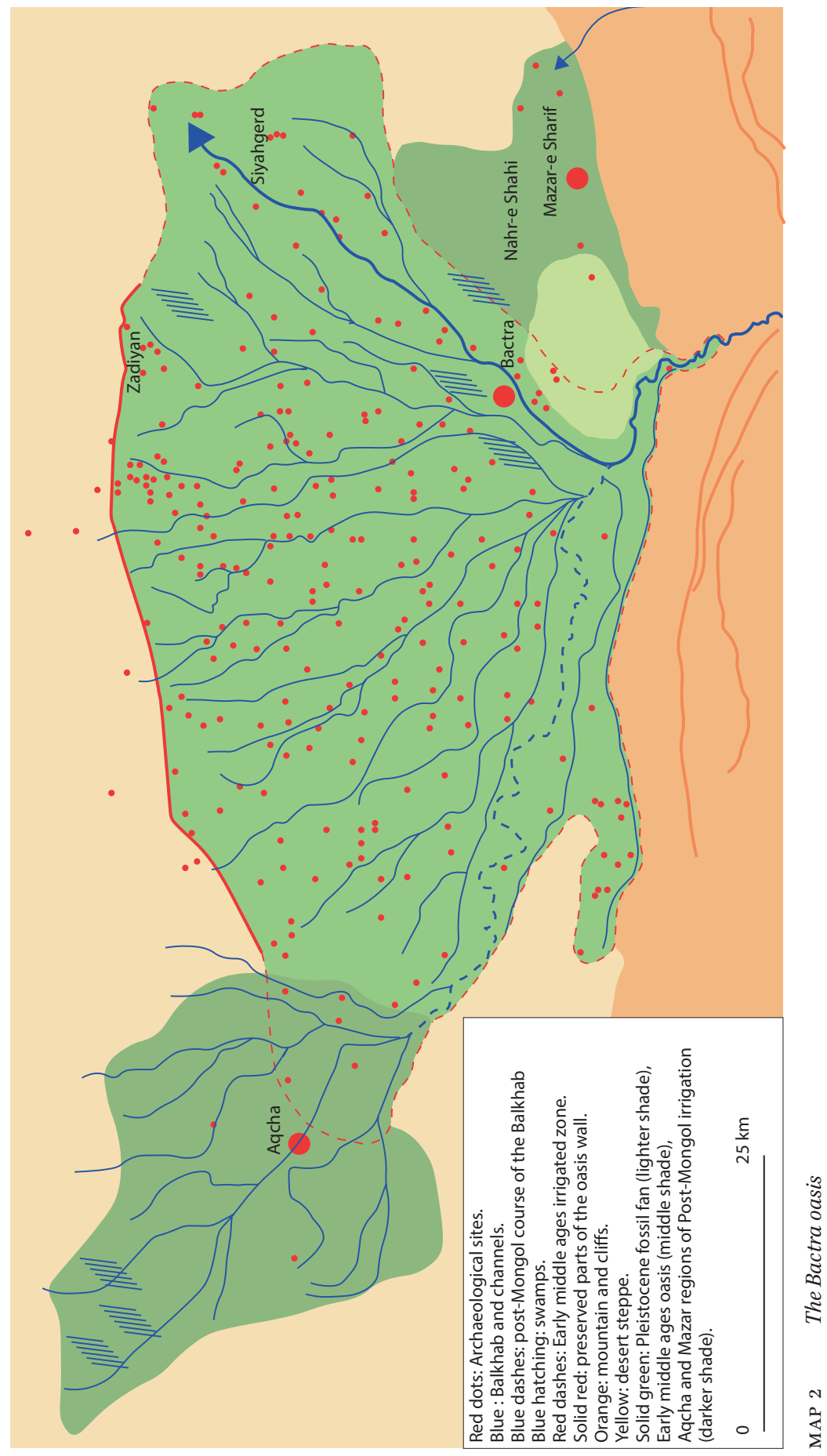


its present course toward the Aqcha secondary cone. This shift has been incorrectly attributed by the team to the $819 \mathrm{AD}$ earthquake; but a 1oth-century text describes the main channel of the Balkh River as still flowing to the northeast. It was rather after the Mongol destruction of the irrigation network that the main flow began to reach Aqcha. ${ }^{36}$ This post-Mongol shift of the Balkhab profoundly modified the shape of the Balkh irrigation, with a substantial increase in its western part and at the same time a major decline of its northeastern and northwestern parts. In these two regions ruined villages and very poorly irrigated fields are everywhere to be seen. These ruins are dated by the presence among them of pre-9th-century Buddhist stupas, 11th-century Ghaznavid fortresses, and 12th-century Seljuk buildings, such those in the vicinity of Zadiyan and Siyahgerd. ${ }^{37}$

This decline should be qualified: if some parts were totally abandoned, it seems that others of them were merely watered less frequently, declining from annually irrigated lands to fallow lands.

This means that the post-Mongol Aqcha cone beyond the wall should be excluded from our study, as should the newly-irrigated Nahr-e Shahi region. But conversely the abandoned villages to the northwest and the northeast should be added, given that they are located within the circumference of the late-antique wall and dotted with early medieval monuments.

With these modifications, the area of the early medieval Bactra oasis can be estimated at approximately $3000 \mathrm{~km}^{2}$; of this area, some $300 \mathrm{~km}^{2}$ were deserts and swamps, as demonstrated by the gaps in archaeological landscape, giving a total irrigated area of $2700 \mathrm{~km}^{2}$. This result, based on hundreds of archaeological sites and an oasis wall, is quite reliable.

The question of the productivity of this land, and the density of population that it was consequently able to sustain, is much more complex. Within the oasis territory there existed gardens, annually irrigated lands, and fallow lands. The oasis walls and the archaeological map give the size of the oasis, but say nothing about the distribution among these categories. It is first necessary to evaluate the productivity of these various categories.

The 8th-century Central Asian data gathered in Xizhou are extremely valuable here for the purpose of comparison, especially when combined with data from 2oth-century northern Afghanistan, particularly an evaluation

36 Actually the raw data of the team do support this later date, a sedimentary sample taken at the apex of the Aqcha cone giving a 1050 to $1550 \mathrm{AD}$ period for the shift: ibid:: 3424 .

37 É. de La Vaissière, Ph. Marquis, "Nouvelles recherches sur le paysage archéologique de Bactres." Compte-Rendus de l'Académie des Inscriptions et Belles-Lettres 2013-3 (2015): 1155-1171. 
of productivity for the oasis of Tashkurgan (Khulm), in the 196os. By then, Tashkurgan was still a heavily traditional oasis, one of the most traditional of a heavily traditional Afghanistan, even more than Balkh, with no improvement in the irrigation or cultivation techniques: no tractors, no concrete irrigation channels, no electric pumps, and with only traditional cultivars. ${ }^{38}$

This oasis has been extensively studied by geographers and ethnographers precisely because of its backwardness. Pierre Centlivres has gathered data on the productivity of the various land uses: 4 jirib of garden or 10 to 12 jirib of cereal (wheat) land might feed a family of 5 . With one jirib being $1954 \mathrm{~m}^{2}$, we arrive at population densities of 6.2 people per hectare for gardens, 2.3 per hectare for (wheat) irrigated land, 1.2 per hectare for biennial fallow lands, 0.76 per hectare for triennial ones, and 0.57 people per hectare for quadriennial fallow lands. ${ }^{39}$

These Tashkurgan data are supported for Balkh by other ethnographic data collected at the end of the 196os: the Fayzabad canal could feed 30,00o inhabitants on 240,000 jirib, i.e. 0.64 people per hectare in a region in which most of the lands were quadriennial fallow lands sown in wheat. ${ }^{40}$ If watered continuously, it would be $4 \times 0.64=2.6$ people per hectare, and actually slightly less, as around the villages there were annually irrigated lands and a few gardens which should be excluded. This number is very close to the 2.3 people per hectare for Tashkurgan. But the main point is that it is also very close to the number deduced from Xizhou 8th-century documents, 2.1 people per hectare for less productive land.

We have a fourth source giving the same result: the 1897 census of the Russian Empire gives a population of 110,000 for the Kattakurgan $u e z d$, in the Zarafshan valley: ${ }^{41}$ while the $u e z d$ was quite large, the population of its extensive steppe and mountain districts, which together comprised a large proportion of its overall territory, amounted to little more than 10 ooo people. The population was concentrated in a $500 \mathrm{~km}^{2}$ annually irrigated zone in the Zarafshan valley: the ratio is once more approximately 2 people per hectare (but includes obviously a few garden zones).

38 P. Gentelle, "L’oasis de Khulm." Bulletin de l'Association de géographes français 46 (1969): 383-393.

P. Centlivres, Un bazar d'Asie centrale: forme et organisation du bazar de Tāshqurghān (Afghanistan) (Wiesbaden: Reichert. 1972): 24.

40 Ministry of Planning, Services for children within regional developement zones. Research and action experimental activities at village level, vol. II, Monographs, (Kabul: CINAM, $1974)$ ): II-93.

http://demoscope.ru/weekly/ssp/rus_gub_97.php?reg=83. 
From these four independent sources, three ethnographic, and one ancient, it might be concluded that an average measure of productivity on a annually irrigated land sown in traditional cultivars should be estimated at around 2.1 persons per hectare. When the land is left fallow, this number should be divided by the number of years of the fallow cycle. The notion of traditional cultivars is a weak point as I cannot prove that the cultivar mix was already the same in the Early Middle Ages, although the idea of a less efficient mix in the 2oth century is much less likely than the opposite.

We are fortunate enough to have a source for the upper limit of productivity in the Bukhara oasis in the early 1oth century. This is the Kitāb al-masālik al-mamālik, a geographical work by al-Ișțakhrī. In the work, al-Iștakhrī writes that "on the cultivated land ('imāra) of Bukhara, it is often possible (rubbamā) for one man cultivating one jarib of land to be fed with it."42 The value of the medieval jarīb was smaller than the 2oth-century Afghan jirib, and varied between $1360 \mathrm{~m}^{2}$ and $1592 \mathrm{~m}^{2}$; taking these varying dimensions into account, the population density in 1oth-century Bukhara can be estimated at somewhere between 6.4 and 7.3 people per hectare for the most productive lands. Once again, our estimated figure corresponds closely, and independently, with the figure of 6.2 people per hectare noted by Gentelle and Centlivres in the 1960 for the very dense part of the traditional Tashkurgan oasis, and also to the numbers for the best lands of 8th-century Xizhou.

The ancient distribution of land within the oasis of Bactra is unknown. This would be certainly the main weakness of the demonstration if we were not seeking minimum numbers, instead of absolute ones. In the absence of historical data, let us turn instead to the detailed land use map created by the un Food and Agricultural Agency just after the end of the Soviet-Afghan war, in 1990-93. This differentiates gardens from both annually irrigated territory and fallow land.$^{43}$ Fallow lands, within the limits of the irrigated zone in the Early Middle Ages, cover $1,800 \mathrm{~km}^{2}$. Annually irrigated lands cover $900 \mathrm{~km}^{2}$, and gardens just $20 \mathrm{~km}^{2}$. The map does not differentiate between quadrennial, triennial and biennial fallow lands. Assuming that these fallow lands were in use every

Ișțahrī, Michael Jan De Goeje (ed.), Kitāb al-masālik al-mamālik, (Leiden: Brill, 1967): 312; in the parallel text in Ibn Hawqal, JH Kramers, \& G Wiet (ed.), Configuration de la terre (Paris: Maisonneuve \& Larose. 1964): 468 the translators choose to incorporate in their text a gloss preserved in only one manuscript, falsely adding a whole family and some servants on the same plot.

43 http://afghanag.ucdavis.edu/country-info/Province-agriculture-profiles/province-mapsaims/Map_AIMS_Balkh.pdf. 
four years, and making use of the density calculated above-namely 2.1 people per hectare for annually irrigated land, $0.5^{2}$ per hectare for quadrennial fallow land, and 6.2 people per hectare for garden land-, this would suggest a poten-

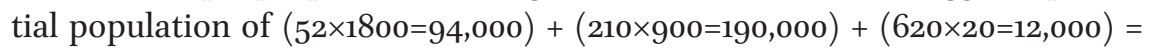
c. 300,000 inhabitants. If the fallow land were in use on a triennial schedule, we might revise the total figure to 325 ,000 inhabitants, and if - an unlikelier possibility-it were used biennially, we might revise the figure to approximately 400,000.

Is this 300,000-400,000 range believable? In 1978, without any large-scale improvement to the irrigation network, though admittedly in improved sanitary conditions, the oasis, including Aqcha, Nahr-e Shahi and Mazar-e Sharif, by then a town of 100,000 inhabitants, was inhabited by approximately 500,000 persons.

We can feel reasonably confident, then, in saying that in the Early Middle Ages the oasis of Bactra could have fed 300,000-400,000 inhabitants. Indeed, the figure may have been higher. From the very beginning of our present discussion we have chosen minima: for instance the 1.2 liter of millet per day is a ratio calculated for grown-up men serving in the Chinese army. This means that more children and women could be fed on the same area than anticipated. The same basis of 1.2 liters of millet would also mean that the whole caloric intake would come from cereals, while obviously part of it should derive from dairy products, meat, and fruits, so that more people could be fed on the same area. A third minimum is the quantity of water: it is very clear from the ethnographic parallels in Tashkurgan that only the quantity of water constrains the annual irrigation of many lands in the oasis. The extent to which lands need to be left fallow is linked not to the quality of the earth - there is no salinization in these traditionally irrigated oases - but to the quantity of water. It is quite probable that the climate was slightly more wet in the Early Middle Ages, and the size of the Aqcha secondary cone, much bigger that the desiccated parts of the Bactra oasis, indicates that more water was available to the Bactra fan before the shift of the river: it could irrigate the now-desiccated parts and provide more water in the still-irrigated ones, modifying the fallow regime. A fourth minimum is the fact that there might have been much more than $20 \mathrm{~km}^{2}$ for gardens in medieval Balkh. I should not be surprised if the oasis of Bactra was populated by 500,000 people in its heyday.

Clearly, though, it was nowhere near so heavily populated in the $7^{\text {th }}$ and 8th centuries: according to the Chinese pilgrim Xuanzang, in 630 the town of Bactra was an empty shell of walls. It was rebuilt only one century later. But a map of the fortresses dotting the landscape, evenly distributed within the 
oasis wall, show that the region may indeed have had a population of 500,000 people during more prosperous periods, such as for instance the Kushan and Kushano-Sasanian eras.

With Bactra we dealt with a less-than-satisfactory case, but still with some convergent sets of data: the archaeological map and the wall of the oasis do point to a continuity of the organization of settlements and irrigation networks, once the major post-Mongol shift of the Balkhab has been taken into account. The productivity rates are in accordance with data both from 8-1othcentury Central Asia and from 2oth-century discussions of traditional Afghan agriculture. By focusing on minima, we have sought a not-impossible range of possibility, if not precise numbers.

\subsection{Bukhara}

We have less data on Bukhara. The wall of Bukhara is partly preserved and delimits an area of approximately $3,200 \mathrm{~km}^{2}$ (Map 3). ${ }^{44}$

The early medieval Muslim geographers commonly note that the oasis territory within the walls comprises an area of $12 \times 12$ farsakhs. This territory fits very neatly into the preserved parts of the wall. ${ }^{45}$

A small part of the oasis lay outside the wall, controlled by the independent principality of Paykent, on the road to the Amu Darya crossing, adding a few hundred square kilometers. Soviet-era hydrological changes mean that the irrigation network as it currently exists is almost entirely useless for evaluating the ancient feeding capacity of the oasis, although the Arabic texts describe the network, the channels of which can be roughly reconstituted. The abovecited work of al-Iștakhrī demonstrates that the productivity of the gardens was on par with that of best lands in Xizhou or Tashkurgan.

If - in an admittedly speculative move-we were to apply the density calculated for the Bactra oasis (i.e. the distribution of lands between gardens, annually irrigated and fallow lands as found in the Bactrian case), this would allow us to postulate that the oasis could have fed some 360,000 inhabitants. However, it is likely that the actual population of the oasis may have been much greater during its heyday in the Early Middle Ages, especially in the 9th and 1oth centuries. Unlike the case for Bactra, the question of the quantity of water was not a problem for Bukhara: there was more water than needed and it overflowed to a small lake beyond Paykent, on the Qaraqul secondary fan.

\footnotetext{
44 S. Stark, Mirzaaxmedov, Djamal, "Pervye rezul'taty novykh issledovanii oazisnoi steny Bukharskogo Sogda 'Devor-i Kampirak'.' Transactions of the State Hermitage Museum 75 (2015): 77-99.

45 Ibn Hiawqal, Configuration de la terre: 483.
} 


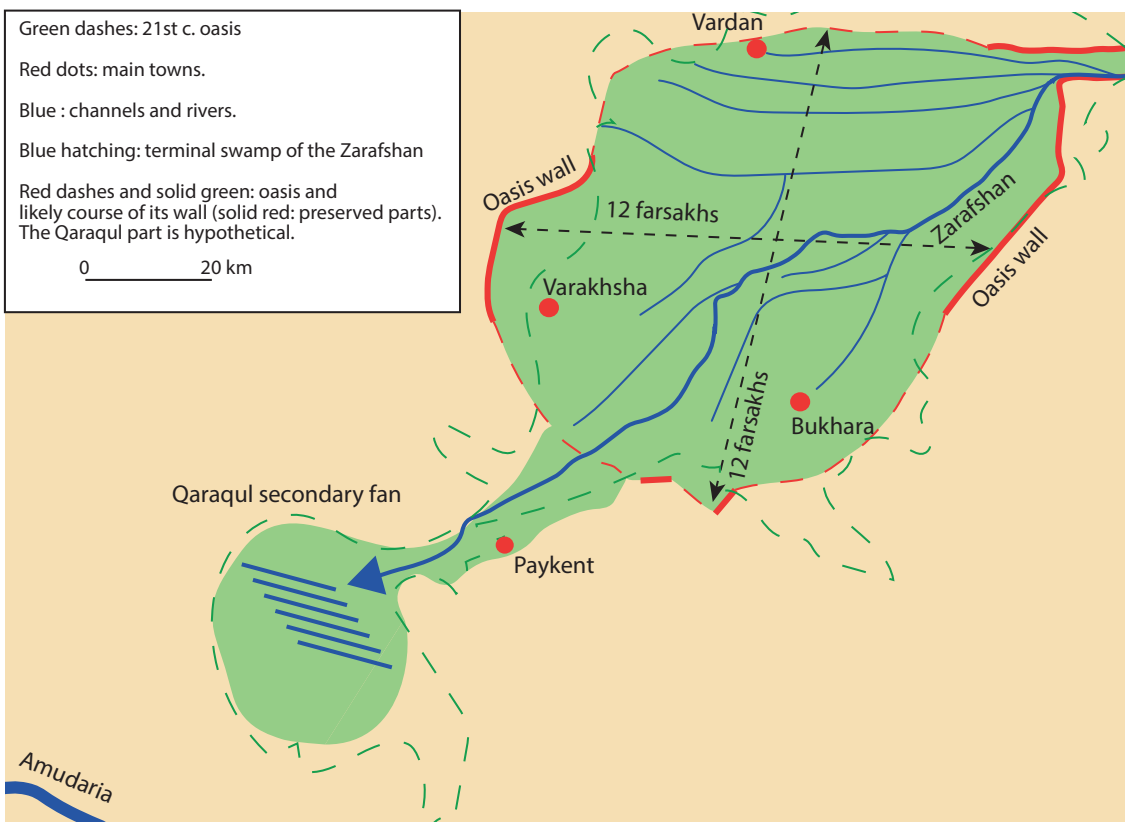

MAP 3 The Bukhara oasis.

This means that there could have been much less fallow land in Bukhara than in Bactra, and much more annually irrigated land. If all the land of the oasis was annually irrigated, then the region of Bukhara-leaving aside Paykent and Qaraqul-could have fed c. 690,00o inhabitants, a maximum that does not take into account the fact that the area of gardens is extremely small in our Bactrian model. Conversely, the excess of water could have created swamps within the oasis, notorious in later periods for its unhealthy conditions.

Our high estimate for the population of early medieval Bukhara finds some support from the works of the 1oth-century Arab geographers. They explicitly describe Bukhara as an oasis without any barren track or fallow land. This might be doubtful on some fringes of the oasis but should be generally true. ${ }^{46}$ They also describe thousands of highly productive gardens in the oasis. ${ }^{47}$ And they add that the population was so numerous that its agriculture could

46 A detailed survey of the Varakhsha region at the western limit of the oasis shows a very dense network of canals and settlements: Ch. Silvi Antonini, Dzh. Mirzaachmedov , Gli scavi di Uch Kulakh (Oasi di Bukhara). Rapporto preliminare, 1997-2007. Rivista degli Studi Orientali LXXX supplemento 1 (2009): map D47. 
not entirely feed it. Grain could be sent from the middle valley of the Zarafshan downstream the river.

It seems clear that when Bukhara was the capital of the Samanid Empire, a number of inhabitants closer to the upper end of the $360,000-690,000$ range is the most likely hypothesis. It may have been lower in the 8th century, but the political geography of the oasis, with the important role devoted to Paykent and Vardan, both on its outer limits, and of Varakhsha, the residence of the Bukharkhuda, also on the fringe of the oasis, strongly points to a densely populated oasis. The actual 8th-century number is however beyond reach.

\subsection{Samarqand and the middle Zarafshan valley}

The structure of irrigation in the middle Zarafshan valley and in Samarqand was very different from the ones described above. This is a valley, not an alluvial fan, with the water naturally flowing along its lowest line. The aim of irrigation is to manage to keep the water as high as possible, by means of carefully designed lateral canals starting far upstream and flowing with as small as possible a vertical incline.

Except for the upper reaches of these canals, the so-called idle part useful only for allowing the canal to reach a controlled altitude, every single plot of land between the canal and the bottom of the valley could theoretically be irrigated (Map 4).

The crucial question is then the date of the various canals irrigating the valley. For our period, we can be certain, because of the distribution of the early medieval settlements, that the Bulungur, the Dargom and the Yangi Ariq were flowing, and that the Miankal, the $820 \mathrm{~km}^{2}$ wet zone between two branches of the river, was drained. ${ }^{48}$ Downstream, the Faiy was also watered. ${ }^{49}$ The question is that of the Chilek region $(\mathrm{A})$ and the zone possibly irrigated by the Eskiangar (B). It seems that the latter was not settled, according to its archaeological remains: it was watered in Antiquity and would be in the Timurid period, but not in between..$^{50}$ With regard to the Chilek region, it is clear that the present canal did not exist, as Ibn Hawqal describes the Widhar-Chilek region as watered by rain and streams, rather than being irrigated. ${ }^{51}$ With these data, the irrigated part of middle valley of the Zarafshan, from Waraghsar to the entrance of the Bukhara fan could be estimated at 3,500 $\mathrm{km}^{2}$. If everything

48 G.A. Pugachenkova, Drevnosti Miankalia (Tashkent: FAN. 1989).

49 Ibn H̦awqal, Configuration de la terre: 496.

$50 \quad$ S. Mantellini, "Irrigation Systems in Samarkand." Encyclopaedia of the History of Science, Technology and Medicine in Non-Western Cultures (2016): 6-7.

$5^{1}$ Ibn Hiawqal Configuration de la terre: 499. 


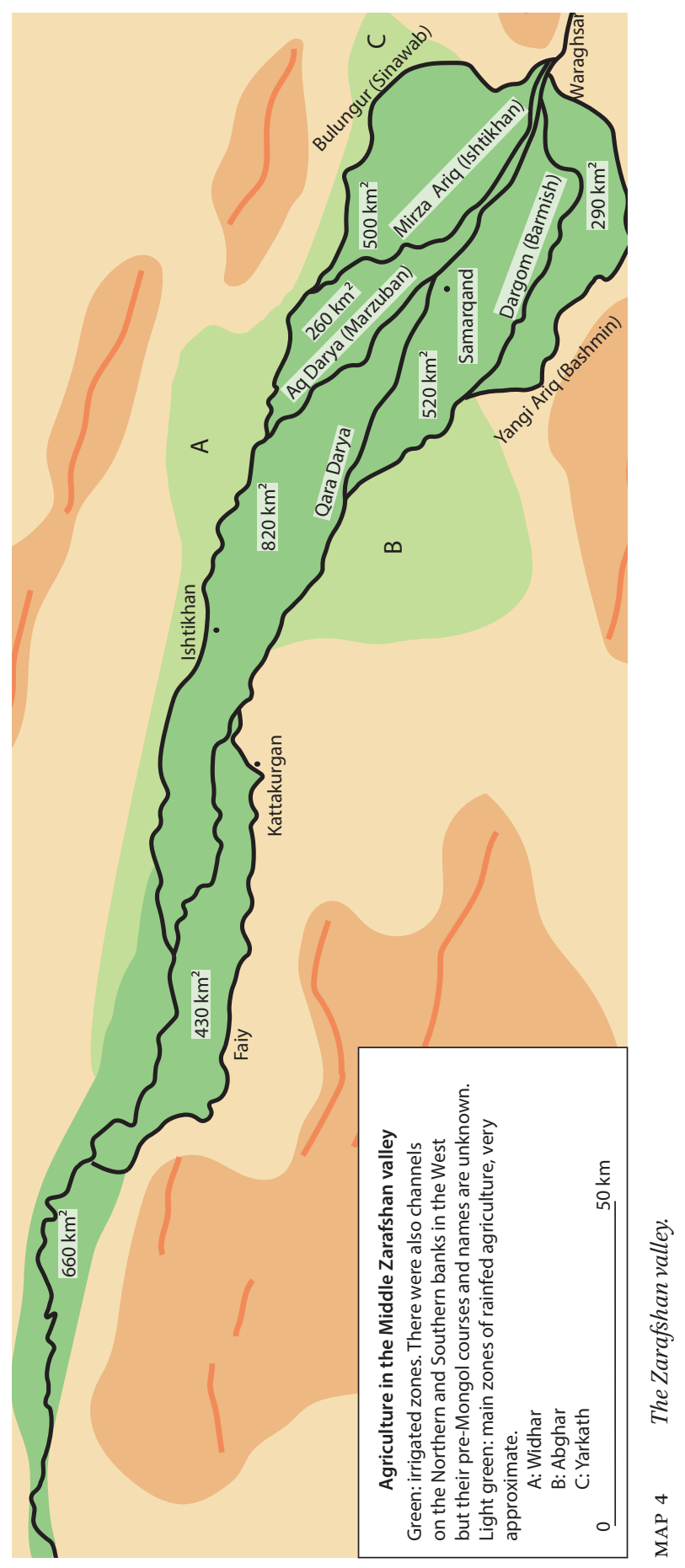


was annually irrigated, a distinct possibility as water was available, then c. 740,000 inhabitants could be fed with grain only.

This is rather a maximum than a minimum, based on the idea that all the available land within canals was watered, a technical possibility which in actual history should only have been true during limited periods. Such was probably not the case in the 8th century with all the disruptions created by the Muslim conquest, but might have been more or less the case during the $7^{\text {th }}$ century or during the heyday of the Samanids. However, even if we might want to reduce this number, we should also increase it: to the products of wheat fields should be added the products of gardens, with their population density of some 620 people per $\mathrm{km}^{2}$ and the dairy products, but also the wheat fields in the lateral zones of the valley, watered only with springs and rain. These pluvial agricultural zones are actually very extensive and cover c. 1,80o km${ }^{2}$, in the Abghar, Chilek and Yarkath regions, and many smaller ones on the foothills. One text says that when the weather was favorable, the yield of Abghar, a $700-\mathrm{km}^{2}$ region of pluvial agriculture (formerly and later partially irrigated by the Eskiangar), could be over 1:100, sufficient to feed the entire Sughd region between the oases of Bukhara and Samarqand..$^{52}$ Even if this is an obvious exaggeration, it still points to very productive agricultural zones to be added to the $3,600-\mathrm{km}^{2}$ irrigated region. I will however calculate according to an average rate: in medieval Iran the taxes of pluvial agricultural lands were $1 / 3$ of the taxes on irrigated land. ${ }^{53}$ Translated into feeding power, these lands would be equivalent to triennial fallow lands, i.e. 70 people per $\mathrm{km}^{2}$, adding c. 120,000 inhabitants possibly fed by the valley. I have to make the hypothesis that the precipitations were at a high level during this period, an idea which seems coherent with the text on the yield of Abghar. This would more firmly put the population of the middle valley of the Zarafshan close to 700,000 or 800,000 inhabitants, as a middle hypothesis. Do we have any data to check that hypothesis?

We have census numbers for the region before the dramatic changes of the agricultural system in the 2oth century. In 1897, the territory comprising the uezds of Samarkand and Kattakurgan, i.e. without the part of the valley in the Emirate of Bukhara downstream, had a population of some 450,000 inhabitants. These uezds, including poorly populated regions, like the mountains surrounding the valley and the upper Zarafshan, comprised $70 \%$ of the agricultural lands in the Zarafshan valley, as the western part, $30 \%$ of the irrigated land within the canals, was in the Emirate of Bukhara (not counting the

52 Ibn Hawqal, Configuration de la terre: 499.

53 Ibid.: 302 . 
Bukhara delta). If we make use of this ratio to calculate the whole population of the middle and upper valley, this would give a c. $640,000\left(=450,000^{*} 10 / 7\right)$ population for the middle and upper valley. This number should in turn be slightly reduced to exclude the Upper Zarafshan and the mountains, giving a total of perhaps $580-600,000$ inhabitants for the middle valley from Waraghsar to the limit of the oasis of Bukhara. However, the archaeological surveys have shown that the valley at the end of the 19th century was far less heavily populated than during its heyday of the 7 th-1oth centuries. Some parts were no longer watered, like the Yangi Ariq zone, and even in the watered part many settlements were not reoccupied after the 1oth century. The number of settlements reached its peak in the 7 th-1oth-century period. There is nothing then implausible in a population somewhere between 700,000 and 800,000 in the 8th century, once the gardens and other intakes reincorporated, and the population could indeed have been substantially greater under the Samanids. We do also have much later data: after the Khorezmian conquest but before the destructive Mongol conquest, Samarqand and its surroundings, but without the valley downstream, were supposedly home to 100,00o households. ${ }^{54}$

If the precise population in the 8th century is unknown, it might have been only slightly below these numbers at the beginning of the 8th century: actually these high numbers for the 1oth century might be interpreted as a recovery. The Arab invasion was extremely destructive in Sogdiana and we might suppose that the population declined between the beginning of the 8th century, before the Arab invasion, and its end, after the destruction of numerous castles, villages and towns which took place, especially under Abu Muslim. We have a few textual data on the early period. When Qutayba b. Muslim besieged Samarqand in $712,130,000$ Sogdians were behind its walls. ${ }^{55}$ It might be supposed that part of the nearby villages' population sought refuge in the town so that Samarqand might have in normal times up to 80,000-100,000 inhabitants. To calculate town populations is extremely difficult due to the variations in density, yet for Panjikent, a small town with an intra-muros area of 13.5 hectares situated $60 \mathrm{~km}$ upstream from Samarqand, excavators have proposed a population of 4,000 to 6,000, which would suggest an extremely high density of 300-450 people per hectare (including temple lands, but not the citadel). ${ }^{56}$ Applied to Samarqand, with its intra-muros area of 205 hectares (without the

54 W. Barthold, Turkestan Down to the Mongol Invasion, ze ed. (London: Luzac, 1968): 88.

55 Ibn A'tham al-Kūfī, Kitāb al-Futūh (Hyderabad : Dāirat al-Ma'ārif al-'Uthmanīya, 1968-75): 7:157.

56 V. Raspopova, Zhilishcha Pendzhikenta (opyt istoriko-sotsial'noi interpretatsii) (Leningrad: 1990): 178-9. 
citadel and the numerous water reservoirs), this would suggest a population of somewhere between 61,000 and 92,000 inhabitants, a range quite in line with the Arabic text on Samarqand in 712. Samarqand was most probably less densely built than Panjikent, but conversely had extensive suburbs. By comparison, Samarqand in 1897 was a town of 55,00o inhabitants, on a different, nearby, site.

As a grand total for the whole Zarafshan valley, with Bukhara, at its agricultural climax under the Samanids, a minimum of 1.3 million, and maybe close to 2 million is to be considered as a likely hypothesis if the numerous depictions of the 1oth-century geographers are accurate in describing a packed region, in terms of agricultural occupation.

The data on the nomadic population of the steppe are even more tentative and coarse. The only numerical data we have are army numbers. The nomads' fearsome military prowess made them objects of concern and curiosity among their sedentary neighbours, who often attempted to monitor their activities. We thus possess a number of Chinese texts giving very global and rough approximations of the number of soldiers that could be mustered by the Qaghans.

One important such text is the official 7th-century history of the Sui dynasty, the Suishu. This work gives a systematic account of the Tiele tribes in ca. $600 \mathrm{AD}$ and gives for the Altay, Tianshan and Syr Daria regions a total of 60,000 soldiers, i.e. 6 groups of cavalrymen each theoretically numbering 10,000 (tümen).${ }^{57}$ We know from less detailed sources that the rival confederacy, that of the Türks, could muster in the same region 10 tümens, and the names of tribes between the two lists do not overlap. ${ }^{58}$

But several questions arise. The first problem is that we do not possess finegrained information about the distribution of nomadic populations, only extremely coarse numbers at the tribal confederacy level. There may well have existed various small- and middle-sized groupings for which we simply do not possess information. Moreover, the precise dates for registering the numbers of soldiers in these two big groups are not known, so that, even if the names of tribes do not overlap, there might have been some transfer of subgroups, especially after the submission of the Tiele to the Türks. But the main problem might lie elsewhere: counting tümens almost certainly overestimates

57 Wei Zheng 魏徵, Suishu 隋書 (Beijing: Zhonghua shuju, 1973): 84: 1879.

$5^{8}$ Liu Xu 劉㽛, Jiu Tangshu 舊唐書 (Beijing: Zhonghua shuju, 1975): 194b: 5188. 
the number of soldiers. Mongol-era sources make clear that in that later period tümens rarely contained their theoretical full complements of 10,000 men, and often contained as few as 3,000 soldiers each. ${ }^{59}$ A figure of 5,000 soldiers per tümen might then be a reasonable average estimate. However, the early 8thcentury Xin Tangshu refers to 20 groups of 7,00o in the same region under the Türgish overlordship of Wuzhile. The text states that "its nomadic encampments gradually get filled. [Wuzhile] established 20 commanders, each of them commanding 7,000 soldiers." It further notes that, in addition to these 140,000 soldiers, 60,000 to 70,000 tribesmen were still loyal to the Ashinas dynasty and migrated eastward to China. ${ }^{60}$ Once more the Turkish source probably said 6 to 7 tümens, which the Chinese writers transcribed 60,000 to 70,000o, but the same question arises. This would provide a grand total of approximately 180-210,000 nomadic soldiers in the region between the Altay and the Tianshan in the early 8th century. Another Chinese text ascribes 200,000 soldiers to the Qaghan Sulu twenty years later, although, once more, the 20 tümens may not have been full. ${ }^{61}$ If however we make use of the middle figure of 5 ,000 soldiers per tümen, then we would arrive at a figure of 130,000 soldiers during Wuzhile's reign, and somewhere in the region of 100,000 under Sulu. I will keep these minimal figures of c. 100-130,000 soldiers.

There remains the challenge of establishing what multiplying factor we need to apply in order to reach an estimate for the population as a whole. Historians of the Mongol Conquest have argued that the huge numbers of soldiers given for the Mongol army can be explained only if a system of universal conscription resulted in the drafting of every single adult male Mongol. ${ }^{62}$ This is what is known as the "people-in-arms theory". In fact, this theory raises a serious problem for the Mongol period. Moreover for the earlier periods, we do have precise texts saying otherwise. Among the Khitans and Jürchens for instance, 2 to 3 tents were supposed to provide one soldier. ${ }^{63}$ Among the Pugu in the 8th c., 10,000 soldiers could be mustered among 30,000 tents and among the Bayarqu 10,000 soldiers among 60,00o tents. ${ }^{64}$ Far from a 1:1 ratio, these numbers vary

59 T. Allsen, Mongol Imperialism: the Policies of the Grand Qan Möngke in China, Russia, and the Islamic Lands, 1251-1259 (University of California Press. 1987): 194. Many thanks to Christopher Atwood for commenting on this part.

6o Ouyang Xiu 歐陽修, Xin Tangshu 新唐書: 215b: 6065-6.

61 Liu Xu 劉昫, Jiu Tangshu 舊唐書: 194b: 5191.

62 J.M. Smith, "Mongol Manpower and Persian Population." Journal of the Economic and Social History of the Orient 18/3 (1975): 271-299.

63 K.A. Wittfogel, \& C. Feng, History of Chinese Society: Liao, 907-1125 (Philadelphia: American Philosophical Society: distributed by the Macmillan Co., New York. 1949): 515-6.

64 Ouyang Xiu 歐陽修, Xin Tangshu 新唐書: 217b: 6139-40. 
between 1:2 and 1:6, and maybe more, as we might suspect that the 10,000 number refers once again to a tümen, which may in fact not have been full. With a 1:2 ratio, and counting 5 people per tent, there would have been a minimum of 1-1.3 million nomads between the Altay and the Tianshan; with a 1:3 ratio, the population would have been closer to 1.5-2 million. In the 1897 Russian census, 2 to 2.5 million nomads were counted as roaming in that part of the region under Russian rule, to which should be added the ones governed by China, all around Dzungaria. By nomads I mean here people drafted into the nomadic armies centered in this region: there should be plenty of sedentary peoples among them, especially in Semirech'e. It is not possible, with our available sources, to know what might have been the unfree populations, maybe not drafted into the military, and maybe large, and more generally to go beyond these very rough numbers.

\section{Conclusion}

I have tried to combine three methodologies to propose an extremely rough idea of what might have been some population minima in Central Asia during the 8th century. In the East, the Chinese census puts us on a reasonably firm basis for some oases, but we do not have any data on some others, especially Khotan. Known numbers are in the range of tens of thousands at most, and the total for the population of all the oases of Eastern Central Asia would appear to have been between 300,000 and 600,000 inhabitants. In Western Central Asia, the numbers that can be deduced from the irrigated areas of the Early Middle Ages are much higher. The Zarafshan valley would seem certainly to have had over 1.3 million inhabitants, and maybe close to 2 million. Bactra should be in the 300- to 400,000 range, varying over time according to the particular historical circumstances. I have dealt with Marw in a separate article, in which I tried to demonstrate that it could not have fed more than 500,00o inhabitants, and more likely $300-400,000 .{ }^{65}$ We do not have ideas for the other regions, like Khorezm, Chāch, Farghana, Kashka Darya, Surkhan Darya and the very numerous small oases (although for some of them in Afghanistan, well enclosed within mountains, it should be possible to propose an evaluation). In the north, we have only army numbers, but a longue durée minimum of 1 million nomads may have lived between the Altay and the Tianshan, and possibly 2.

65 É. de la Vaissière, “The Abbassid Revolution in Marw : New Data." Der Islam (2018): forthcoming. 
All in all, these numbers, however rough, point to some major imbalances in our historical judgements on Central Asia. For instance, although much research has been devoted to the small oases in the East, due to the wealth and distinctive characteristics of their cultural landscape, actually Western Central Asia was five to ten times more heavily populated than Eastern Central Asia. We should be careful not to forget this point when we try to evaluate phenomena like the Sogdian migrations all over Central Asia - the Sogdians were much more numerous than any other local inhabitants; or the geography of Chinese military conquests, which extended across the whole of the poorly populated East, but stopped short of the heavily populated Chāch in the west; or the uncontested nomadic overlordship over Central Asia as a whole-their core populations were sizeable enough, even when compared with the sedentary population of Western Central Asia. Some other results have been mentioned in passing, such as a new point of view on the decline of Tokharian.

These data, however imperfect, do provide a welcome shift in our historical understandings of Central Asia in the Early Middle Ages.

\section{Bibliography}

al-Qāḍī, Wadād. 2008. Population Census and Land Surveys under the Umayyads (41-132/661-750). Der Islam 83: 341-416.

Allsen, Thomas T. 1987. Mongol Imperialism: the Policies of the Grand Qan Möngke in China, Russia, and the Islamic Lands, 1251-1259. University of California Press.

Barthold, Wilhem. 1968. Turkestan down to the Mongol Invasion, 3rd ed. revised by C.E. Bosworth. London: Luzac.

Bielenstein, Hans. 1947. The Census of China during the Period 2-742 AD. Bulletin of the Museum of Far Eastern Antiquities 19: 125-163.

Centlivres, Pierre. 1972. Un bazar d'Asie centrale: forme et organisation du bazar de Tāshqurghān (Afghanistan). Wiesbaden: Reichert.

Du You 杜佑. 1988. Du You 杜佑, Tongdian 通典. Beijing: Zhonghua shuju.

Emmerick, Ronald Eric. 1967. Tibetan Texts Concerning Khotan. Oxford: Oxford University Press.

Fouache, Eric, Roland Besenval, Claude Cosandey, Céline Coussot, Matthieu Ghilardi, Sébastien Huot, \& Michel Lamothe. 2012. Palaeochannels of the Balkh river (northern Afghanistan) and human occupation since the Bronze Age period. Journal of Archaeological Science 39: 3415-3427.

Gentelle, Pierre. 1969. L'oasis de Khulm. Bulletin de l'Association de géographes français 46: 383-393. 
Graff, David. 2003. Medieval Chinese Warfare 300-9oo. Abington: Routledge.

Hudūd al-'Alam. 1970. Hudūd al-'Alam: "The Regions of the World". A Persian Geography, 372 A.H.-982 A.D. Translated and explained by Vladimir Minorsky. London: Luzac.

Ibn A'tham al-Kūfî. 1969-76. Kitāb al-Futūh. 8 vols. Hyderabad : Dā'irat al-Ma'ārif al-'Uthmanìya.

Ibn Hawqal. 1964. Configuration de la terre, ed. Johannes Hendrik Kramers, \& Gaston Wiet Paris: Maisonneuve \& Larose.

Ișțakhrī. 1967. Kitāb al-masālik al-mamālik, ed. Michael Jan De Goeje. Bibliotheca Geographorum Arabicorum, I. Leiden: Brill, zrd ed.

La Vaissière, Étienne de, Philippe Marquis. 2015. Nouvelles recherches sur le paysage archéologique de Bactres. Compte-Rendus de l'Académie des Inscriptions et BellesLettres 2013-3: 1155-1171.

La Vaissière, Étienne de, Philippe Marquis, Julio Bendezu-Sarmiento. 2015. A Kushan military camp near Bactra. In Kushan Histories. Literary Sources and Selected Papers from a Symposium at Berlin, December 5 th to 7 th, 2013, ed. H. Falk. Monographien zur indischen Archäologie, Kunst und Philologie, 23. Bremen: Hempen Verlag: 241-254.

La Vaissière, Étienne de. 2018. The Abbassid Revolution in Marw: New Data. Der Islam: forthcoming.

Li, Jifu 李吉甫. 1983. Li Jifu 李吉甫, Yuanhe junxian tuzhi 元和郡縣圖志. Beijing: Zhonghua Shuju.

Liu, Xu 劉 昫. 1975. Liu Xu 劉 昫, Jiu Tangshu 舊唐書. Beijing: Zhonghua shuju.

Mantellini, Simone. 2016. Irrigation Systems in Samarkand. Encyclopaedia of the History of Science, Technology and Medicine in Non-Western Cultures. Dordrecht: Springer Netherlands.

Ouyang, Xiu 歐陽修. 1975. Ouyang Xiu 歐陽修, Xin Tangshu 新唐書. Beijing: Zhonghua shuju.

Pugachenkova, Galina A. 1989. Drevnosti Miankalia. Tashkent: FAN.

Raspopova, Valentina. 1990. Zhilishcha Pendzhikenta (opyt istoriko-sotsial'noi interpretatsii). Leningrad: Nauka.

Silvi Antonini, Chiara, \& Džamal Mirzaachmedov. 2009. Gli scavi di Uch Kulakh (Oasi di Bukhara). Rapporto preliminare, 1997-2007. Rivista degli Studi Orientali LXXX supplemento 1.

Skaff, Jonathan Karam. 1998. Straddling Steppe and Sown: Tang China's Relations with the Nomads of Inner Asia (640-756). Unpublished Ph.D. Dissertation. University of Michigan.

Smith, John Masson. 1975. Mongol Manpower and Persian Population. Journal of the Economic and Social History of the Orient 18/3:271-299. 
Stark, Sören, Mirzaaxmedov, Djamal. 2015. Pervye rezul'taty novykh issledovanii oazisnoi steny Bukharskogo Sogda 'Devor-i Kampirak'. Transactions of the State Hermitage Museum 75: 77-99.

Stein, Aurel. 1921. Serindia. Oxford: Clarendon Press.

Su Jinhua 苏金花, “Monographic Study on Agriculture of Dunhuang during the Tang and Five Dynasties 唐五代敦煌农业专题研究, ”中国社会科学院研究生院: 2002.

Trombert, Éric. 2002. Les cycles de culture et l'organisation des terroirs à Tourfan aux VI ${ }^{\mathrm{e}}-\mathrm{VIII}{ }^{\mathrm{e}}$ siècles. Bulletin de l'Ecole française d'Extrême-Orient 89: 203-235.

Trombert, Eric. 2002. La vigne et le vin en Chine: Misères et succès d'une tradition allogène. Journal asiatique 290/2: 485-563.

Trombert, Eric. 2011. Notes pour une évaluation nouvelle de la colonisation des contrées d'Occident au temps des Han.Journal Asiatique 299/1: 67-123.

Wei, Zheng 魏徵. 1973. Wei Zheng 魏徵, Suishu 隋書, Beijing: Zhonghua shuju.

Wittfogel, Karl August, \& Chia-sheng Feng. 1949. History of Chinese Society: Liao, 9071125. Philadelphia: American Philosophical Society.

Wu Zhen 吴震. 1982. Edition and Commentary of the Junxian Gongxie Benqian Bu 敦煌 石室写本唐天宝初年〈郡县公廨本钱簿〉校注并跋. Wenshi 文史 93: 97-98.

Xiong, Victor Cunrui. 1999. The Land-Tenure System of Tang China-A Study of the Equal-Field System and the Turfan Documents. T'oung Pao 85: 328-390.

Yin Qing 殷晴. 2007. The Silk Road and the Economy of the Western Regions (丝绸之路 与西域经济). Beijing: Zhonghua Shuju.

Zürcher, Erik. 1990. Han Buddhism and the Western Region. In Thought and Law in Qin and Han China. Studies dedicated to Anthony Hulsewé on the Occasion of his Eightieth Birthday, ed. W. L. Idema and E. Zürcher. Leiden: Brill: 158-182. 